\title{
Risk Management in Collegiate Sports: Whose Responsibility?
}

\author{
Kimberly Bodey, BS, M.Ed. \\ Assistant Women's Track Coach \\ University of lowa 182 Westside Dr. \#4 • lowa City, IA 52246 \\ Phone - 319-335-9228•Fax-319-335-9333•kim-bodey@uiowa.edu \\ Merry Moiseichik, BSE, M.Ed., Re.D. \\ Associate Professor of Recreation Administration \\ University of Arkansas - HPER 308X • Fayetteville, AR 72701 \\ Phone 501-575-2870• Fax 501-575-5778・merry@comp.uark.edu
}

As litigation for sport related injuries has increased in recent years, so has awareness by coaches and administrators that their action, or inaction, will be judged in a court of law. Risk management is a process that has evolved from necessity. It involves understanding and identifying those situations where accidents may occur and making the required changes to minimize the occurrence (Dougherty, 1993). A fundamental characteristic is that risk management is a proactive, preventive method (Gray \& McKinstrey, 1994).

Collegiate athletics has evolved also. Once fee-sponsored, athletics is now deep pocket, win at all costs, big business that impacts public relations, and ultimately, the financial stability of an institution. This awareness has forced university officials to take an in-depth look at how various risk management practices influence the functioning of collegiate athletic programs. However, institutions have been slow to make the requisite change(s) to protect against potential litigation and resultant financial loss. Therefore, the question remains: should universities be allowed to voluntarily comply with standard risk management practice or should compliance be mandated through regulation? The purpose of this study was to determine the degree to which Southeastern Conference (SEC) head coaches endorse regulation of risk management practice, and further, if regulated, what organization should be responsible for developing and enforcing the regulations.

In 1906, the National Collegiate Athletic Association (NCAA) was created as a self gov- erning body of colleges and universities to regulate intercollegiate athletics. The NCAA membership, over 700 colleges and universities nationwide, creates the rules and regulations for competition, eligibility, and recruitment of student athletes. The NCAA Constitution and the NCAA Manual comprise most of the guidelines for member institutions. Article 2 of the NCAA Constitution addresses the principles of conduct of intercollegiate athletics, and specifically states in "the principle of student-athlete welfare" that "it is the responsibility of each member institution to protect the health and provide a safe environment for each of its participating studentathletes" (1998, p. 3). Student-athletes rightfully assume that those responsible for conducting intercollegiate athletics have taken reasonable precautions to minimize the risk of significant injury.

Recognizing risk is a preeminent task of an organization. As the number of liability suits and resultant liability insurance increase, the responsibility for risk management lies with every member of the organization whether administrative, supervisory, or direct service personnel (Peterson $\&$ Hronek, 1992). A review of literature identified studies assessing risk management behavior of high school principals (Gray, 1995), high school athletic directors (Gray \& Parks, 1991), NCAA Division I athletic directors (Gray \& Crowell, 1993), NCAA Division III athletic directors (Anderson \& Gray, 1992), NCAA Division III head football coaches (Gray \& McKinstrey, 1994), sport facility managers (Pyles \& Pyles, 1992), and wilderness outfitters and guides in 
North America (Gray, 1992). In all of Gray's articles, there is a strong indication that risk management is being handled. One must wonder, however, how good a job is being done when the national news announced that three collegiate wrestlers died while trying to drop weight quickly by riding a bike in a sauna. All three were under coach's supervision and still engaging in an activity that put their lives in jeopardy. At almost any university, one can witness that appropriate risk management strategies are not in place. For example, last fall during a University of Arkansas football game there was a serious threat of tornado. At that time the administration realized they had no idea how to react as there was no emergency action plan, one of the most common strategies for prevention. Who should have checked for this? Who should enforce that it is in place?

In all physical activity there is potential risk of injury. Risk is often the unique characteristic that gives participation meaning and hence its worth. With participation, however, comes responsibility often delegated to the administrators and personnel of the activity (Gray, 1992). But, until a problem is evident, risk management may be left to chance. The purpose of this study was to examine whether coaches feel risk management should be left to chance or regulated. If risk management should be regulated, who should be responsible: the NCAA, SEC Conference, university, or sport specific national governing body.

\section{Methodology}

The subjects selected for this study were head coaches representing 20 men and women's sports in the Southeastern Conference $(N=169)$. A 30-item questionnaire developed by the investigator was used to collect data related to the strength of feeling about specific risk management practices in SEC athletic departments and the need for regulation. Various risk management behaviors were divided into five conceptual areas including: a) supervision, b) facilities and equipment, c) emergency and medical care, d) travel and transportation, and e) due process for employees and student athletes when they feel they have been not received fair treatment.

A Likert-type scale of 1 to 5 was used to specify the degree to which head coaches believe that risk management practice identified in the survey statement should be regulated.
The scale suggested strength of feeling such that " 1 " indicated strongly disagree, " 2 " - disagree, " 3 " - no feeling, "4" - agree, and "5" - strongly agree. Further if " 4 " - agree or " 5 " - strongly agree was indicated, coaches were asked to identify which organization (NCAA, SEC, institution, national governing body or other) should regulate the practice. To check for validity, a panel of coaches representing universities in other conferences reviewed the questionnaire.

In addition to the 30 risk management behavior questions, data were collected for 8 demographic variables including staff size, coaching experience, education level and degree area, CPR and first aid certifications, gender of athletes coached, and risk managers on staff. The questionnaires were coded for the second mailing and to insure confidentiality.

\section{Results and Discussion Demographic data}

The original mailing and follow-up mailing of the surveys to 169 SEC head coaches resulted in a return rate of $57.9 \%(\mathrm{~N}=98)$. Table 1 lists relevant demographic data for the subjects. The data indicated that approximately the same number of subjects possessed undergraduate as graduate degrees, many of whom have had professional preparation in sport related (sport management, physical education) areas. Sixty-two subjects said a person on staff at the institution is responsible for overseeing risk management practices while far less had an individual on the specific sport staff responsible for risk management. For this study, individual sports are those that a participant may earn a victory regardless of the team score (i.e. cross country, golf, tennis). A team sport was one that all participants contributed to a single outcome (i.e. baseball, soccer, softball). Additionally, revenue sports were limited to men's football and basketball.

Table 2 shows the ranked means and corresponding standard deviations for each of the 30 survey items among all respondents $(\mathrm{N}=98)$. According to the data, SEC head coaches indicated that most risk management practices should be regulated ( 25 of 30 survey items had means exceeding 4.0 on a 5-point scale). All but one survey item had means greater than 3.5. This support of regulation may be the result of several factors. First, the relatively high degree of consistency with which coaches say that they support regulation suggests that they are experienced people $(M=16.14$ years $)$. Certainly, dur- 


\begin{tabular}{|c|c|c|}
\hline Staff & \multicolumn{2}{|c|}{$\underline{M}=8.5$ Assistants $($ Range $=1-69)$} \\
\hline Education & $\begin{array}{l}\text { Bachelor } \\
\text { Master } \\
\text { Doctoral }\end{array}$ & $\begin{array}{l}=45(45.9 \%) \\
=44(44.2 \%) \\
=2(2.0 \%)\end{array}$ \\
\hline Area of Highest Degree & $\begin{array}{l}\text { Sport-related } \\
\text { Nonsport-related }\end{array}$ & $\begin{array}{l}=40(40.8 \%) \\
=44(44.9 \%)\end{array}$ \\
\hline Coaching Experience & $\underline{M}=16.14$ years ( & $2-33)$ \\
\hline First Aid Training & $\begin{array}{l}\text { Certification } \\
\text { No certification }\end{array}$ & $\begin{array}{l}=34(34.7 \%) \\
=57(58.2 \%)\end{array}$ \\
\hline CPR Training & $\begin{array}{l}\text { Certification } \\
\text { No certification }\end{array}$ & $\begin{aligned}= & 45(45.6 \%) \\
& =49(50 \%)\end{aligned}$ \\
\hline $\begin{array}{l}\text { Risk Manager at } \\
\text { Institution }\end{array}$ & $\begin{array}{l}\text { Yes } \\
\text { No }\end{array}$ & $\begin{array}{l}=62(61.2 \%) \\
=19(19.4 \%)\end{array}$ \\
\hline $\begin{array}{l}\text { Risk Manger on } \\
\text { Sport staff }\end{array}$ & $\begin{array}{l}\text { Yes } \\
\text { No }\end{array}$ & $\begin{array}{l}=24(24.5 \%) \\
=60(61.2 \%)\end{array}$ \\
\hline Athlete Gender & $\begin{array}{l}\text { Male } \\
\text { Female } \\
\text { Male and female }\end{array}$ & $\begin{array}{l}=43(43.9 \%) \\
=43(43.9 \%) \\
=9(9.2 \%)\end{array}$ \\
\hline $\begin{array}{l}\text { Team vs. Individual } \\
\text { Sport }\end{array}$ & $\begin{array}{l}\text { Team } \\
\text { Individual }\end{array}$ & $\begin{array}{l}=43(43.9 \%) \\
=46(46.9 \%)\end{array}$ \\
\hline $\begin{array}{l}\text { Revenue vs. Nonrevenue } \\
\text { Sport }\end{array}$ & $\begin{array}{l}\text { Revenue } \\
\text { Nonrevenue }\end{array}$ & $\begin{array}{l}=19(19.4 \%) \\
=70(71.4 \%)\end{array}$ \\
\hline
\end{tabular}

Note: Percentages do not add to $100 \%$ as missing values are not included.

ing their tenure, coaches have experienced a situation that was beyond their level of expertise. In essence, regulation would provide some minimum knowledge and standard of behavior from which to act. Second, coaches genuinely do not want to see athletes injured, for the sake of an athlete and the team. Having various risk management policies and procedures in place will likely reduce the chance that an unforseen accident will occur. More important, the coach will be prepared to deal efficiently and effectively with any situation should it arise. This would reduce the potential for allegations of negligence. Third, currently the NCAA provides guidelines to its member institutions in the area of emergency and medical care. Guidelines do very little because interpretations vary based on the administration's value system and experience. Coaches may seek a more objective standard from which to justify actions. Also, emergency and medical care is only a small part of the athletic realm. Regulation in the other conceptual areas is necessary.

Table 3 shows the ranked means and standard deviations calculated for each of the five conceptual areas for all subjects combined $(\mathrm{N}=98)$. The data showed that the highest ranked conceptual area was emergency and medical care of athletes (4.26) while the lowest ranked conceptual area was supervision of athletes (3.96). The indication that emergency medical care and due process should be regulated may reflect coaches' low level of comfort with their knowledge in these areas. Regulation would provide information and a standard of behavior in areas that might otherwise be lacking. Supervision is an inherent part of practice; therefore, this integral part of the profession is not necessary to regulate.

\section{Analysis by Gender of Athletes Coached}

Once the data were compiled, normalcy was checked. Because the population was not normally distributed, nonparametric tests were done. A .10 level of significance is appropriate when using nonparametic tests (Schlotzhauer \& Littlell, 1987).

Statistical analyses of the five conceptual areas addressed in the questionnaire were ana- 
Table 2: Ranked means and standard deviations for each survey item $(\mathrm{N}=98)$

Risk management behavior

Annual pre-participation physicals required

Accurate medical record maintained

After injury, permission from MD to participate

Coach knows first aid, injury prevention

Policies are clearly stated and enforced

Appropriate supervision in all settings

Telephone/emergency numbers available

Due process policies/procedures clearly stated

Evaluation policies/procedures clearly stated

Proc. for investigating and reporting injuries

Policies/procedures for hiring and firing

Facilities are regularly inspected

Licensure/safety records for travel verified

Job description for each position on file

Recommended sequence for safe performance

Staff knowledgeable about tort liability

Maintain records regarding qualifications

Prior to prac./EAP written and followed

Review rules/safety policies with athletes

Legal counsel available

Inventory files maintained

Athletes aware of shared responsibility for safety

Rank

1

2

3

4

4

6

7

8

9

10

10

10

13

14

15

16

17

18

18

20

21

22

23

24

25

26

27

28

29

30
Mean

4.847

4.786

4.174

4.490

4.490

4.412

4.392

4.357

4.296

4.286

4.286

4.286

4.240

4.173

4.155

4.137

4.102

4.071

4.071

4.062

4.061

4.020

4.011

4.000

4.000

3.959

3.949

3.939

3.561

3.490
S.D.

.439

.482

.609

.721

.707

.899

.771

.777

.852

.802

.786

.873

1.001

.874

1.004

.895

.879

1.067

.987

.960

.982

.908

1.087

.974

1.026

1.102

1.069

1.001

1.210

1.046 lyzed by the gender of the athletes being coached. Coaches said they coached "females only", "males only", or "both males and females". Significant differences existed in two of the conceptual areas: supervision and emergency and medical care.

Table 4 shows the results of the KruskalWallis test. In the area of supervision, respondents who coach combined teams of males and females scored significantly higher $(M=4.39)$ than coaches of male $(\underline{M}=3.94)$ or female $(\underline{M}=3.84)$ athletes. This may be a result of NCAA mandated staff size and total number of athletes. For example, the NCAA permits track \& field, an equivalency sport with a travel roster of 28 or more athletes, a staff of one head coach and two full time assistant coaches. If the men and women's programs are combined, the NCAA permits only two additional full time assistant coaches which increases the coach-athlete ratio. Regulating supervision would affect the number of coaches on staff, possibly increasing staff size.

In the area of emergency and medical care, coaches of women scored significantly higher

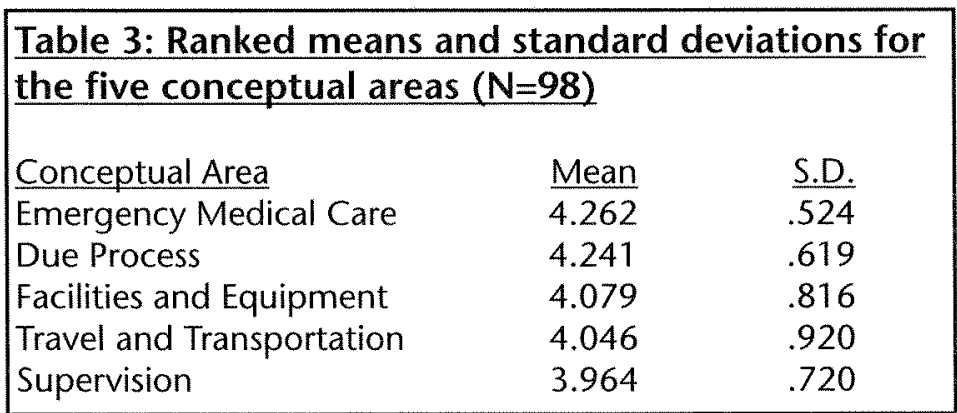


$(M=4.38)$ than those who coach male athletes $(\mathrm{M}=4.07)$. Also coaches of combined male and female athletes $(\underline{M}=4.39)$ scored significantly higher than coaches of male athletes. This may reflect a larger cultural issue which is to protect the health and welfare of women. Regulating emergency and medical care behavior would determine standard risk management behavior to reduce female athletes' exposure to significant injury.

In addition, significant differences existed among three of the 12 emergency and medical and supervision survey items based on athlete gender. The survey items are listed in Table 5. Respondents that coach women scored significantly higher $(M=4.48)$ than those who coach men $(\mathrm{M}=4.00)$ on the survey items regarding "procedures for investigating and reporting injuries." On the same item, respondents who coach combined male and female athletes $(M=4.44)$ scored significantly higher than those who coach men. Again, this reflects the social concern for women. It is necessary to investigate the cause of injury to reduce the likelihood of future occurrence.

The survey item that related to following a "detailed risk management plan during all practices and competitions," showed significant difference. Respondents who coach men and women scored significantly higher $(M=4.33)$ than those who coach men $(\mathrm{M}=3.21)$ or women $(\mathrm{M}=3.52)$. Again, this may reflect staff shortage; coaches dealing with many athletes will rely on a prepared plan to effectively avoid or reduce serious injury.

Regarding "sequential method of instruction" coaches working primarily with men scored significantly higher $(M=4.09)$ than coaches of women $(\underline{M}=3.67)$. Similarly, coaches of both men and women scored significantly higher
$(\underline{M}=4.44)$ than coaches of females. This result may be explained by athletes' relative ability. Female athletes enter college with a greater discrepancy between actual and potential ability because of less involvement, opportunity, or quality coaching during developmental years. Collegiate coaches must rely on sequential training to decrease this disparity (i.e., master skills). Historically, male athletes have entered college with a higher level of actual ability relative to potential ability because of involvement and coaching at the primary level. This trend may be changing. Coaches find that progressive sequential instruction is necessary to master skills. Analysis by Team versus Individual Sport

Statistical analysis of the five conceptual areas addressed in the questionnaire comparing the status as a team versus individual sport showed that a significant difference existed in the conceptual area of facilities and equipment. Table 6 shows the results of the Wilcoxon Rank Sum test. Coaches of team sports scored significantly higher $(\mathrm{M}=4.21)$ than coaches of individual sports $(\underline{M}=3.90)$. There was no significant difference in individual questions, however.

\section{Analysis by Revenue versus Nonrevenue} Sport

Statistical analysis of the five conceptual areas addressed in the questionnaire comparing revenue versus nonrevenue sport showed that a significant difference existed in the conceptual area of facilities and equipment. Table 7 shows the results of the Wilcoxon Rank Sum test. Coaches associated with revenue sports scored significantly higher $(M=4.44)$ than coaches associated with nonrevenue sports $(M=3.45)$ in the conceptual area of facilities and equipment. In revenue sports, facilities and equipment are important recruiting tools. All things being equal, the institution with the finest facilities will have

\begin{tabular}{|c|c|c|c|c|c|}
\hline Conceptual Area & F-Value & F-Prob. & Gender & Mean & S.D. \\
\hline \multirow[t]{3}{*}{ Supervision } & 2.176 & .10 & Male & 3.94 & .742 \\
\hline & & & Female & 3.84 & .696 \\
\hline & & & Male\&Female & 4.39 & .583 \\
\hline \multirow{3}{*}{$\begin{array}{l}\text { Emergency/ } \\
\text { Medical Care }\end{array}$} & 4.377 & .02 & Male & 4.07 & .574 \\
\hline & & & Female & 4.38 & .391 \\
\hline & & & Male\&Female & 4.39 & .570 \\
\hline
\end{tabular}




\begin{tabular}{|c|c|c|c|c|c|}
\hline Survey Item & CHISQ-Value & CHISQ-Prob & Gender & Mean & S.D. \\
\hline $\begin{array}{l}\text { Procedure for } \\
\text { invest. injures }\end{array}$ & 3.86 & .02 & $\begin{array}{l}\text { Male } \\
\text { Female } \\
\text { Male\&Female }\end{array}$ & $\begin{array}{r}4.00 \\
4.48^{*} \\
4.44^{*}\end{array}$ & $\begin{array}{l}1.000 \\
.688 \\
.726\end{array}$ \\
\hline $\begin{array}{l}\text { Risk Plan is } \\
\text { Followed }\end{array}$ & 4.70 & .01 & $\begin{array}{l}\text { Male } \\
\text { Female } \\
\text { Male\&Female }\end{array}$ & $\begin{array}{r}3.21 \\
3.52 \\
4.33^{*}\end{array}$ & $\begin{array}{l}1.071 \\
.994 \\
.707\end{array}$ \\
\hline $\begin{array}{l}\text { Sequential Method } \\
\text { of instruction }\end{array}$ & 2.66 & .07 & $\begin{array}{l}\text { Male } \\
\text { Female } \\
\text { Male\&Female }\end{array}$ & $\begin{array}{r}4.09^{*} \\
3.67 \\
4.44^{*}\end{array}$ & $\begin{array}{r}1.287 \\
1.149 \\
.726\end{array}$ \\
\hline
\end{tabular}

an advantage in recruiting. Institutions with the financial resources may continue to renovate and upgrade facilities and, subsequently, gain a recruiting advantage. Coaches of revenue sports may believe that regulation will prove the needed justification for directing financial resources to upgrade this area. This may not be the case in nonrevenue sports where the coachathlete relationship plays a much larger role in revenue sports $(M=3.88)$ on regulating "appropriate training to fit equipment." This would be essential particularly in football. Poorly fitted equipment can contribute to catastrophic injury. Therefore, it is necessary to have qualified personnel in this area. Revenue sports coaches also scored significantly higher $(M=4.77)$ than nonrevenue sport coaches $(\underline{M}=3.94)$ regarding the survey item related to

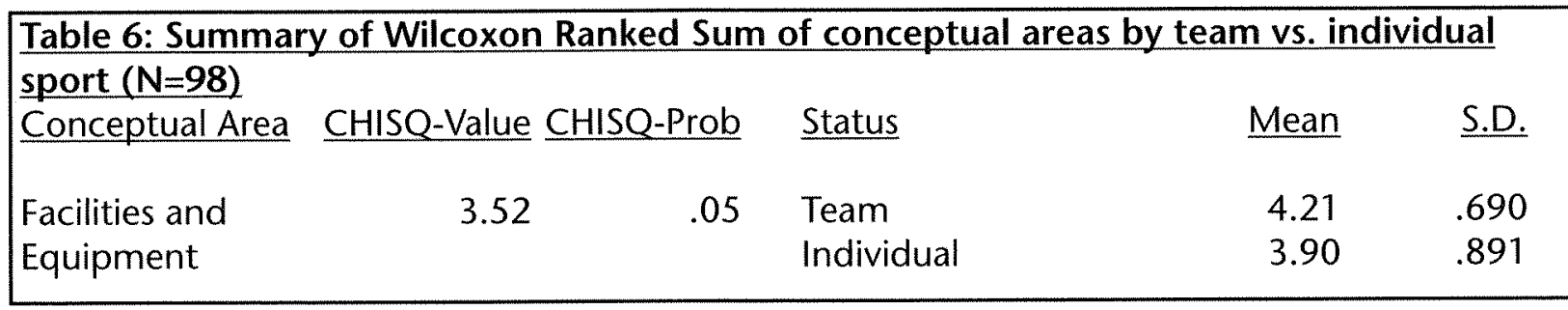

the recruiting process.

Two significant differences existed among the three individual survey items dealing with equipment and facilities based on revenue versus nonrevenue sport status. The survey items are listed in Table 8.

Coaches of revenue sports scored significantly higher $(\underline{M}=4.42)$ than coaches of non- "detailed inventory files are maintained." This may reflect the combination of quantity of equipment (practice gear, competitions gear, equipment, etc.) and people. Detailed inventory records are necessary to help in the auditing process.

Additional Analysis

A Wilcoxon Rank Sum test was used to ex-

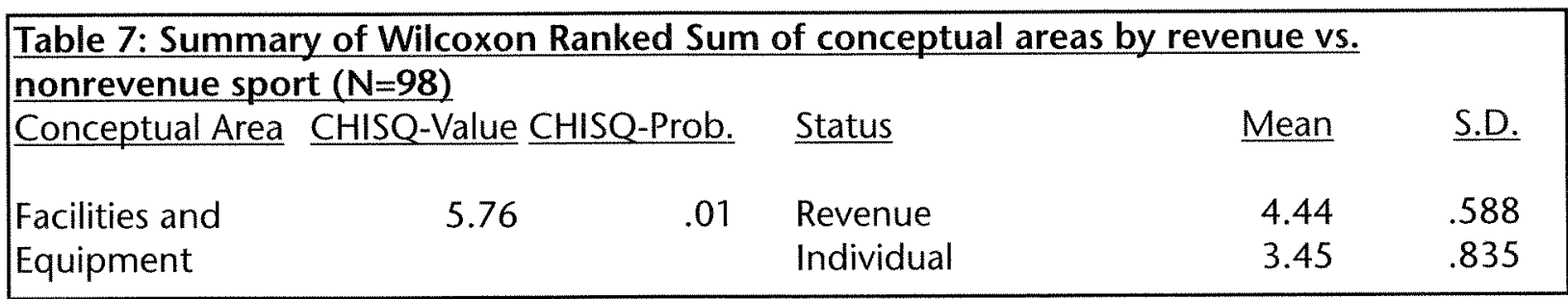




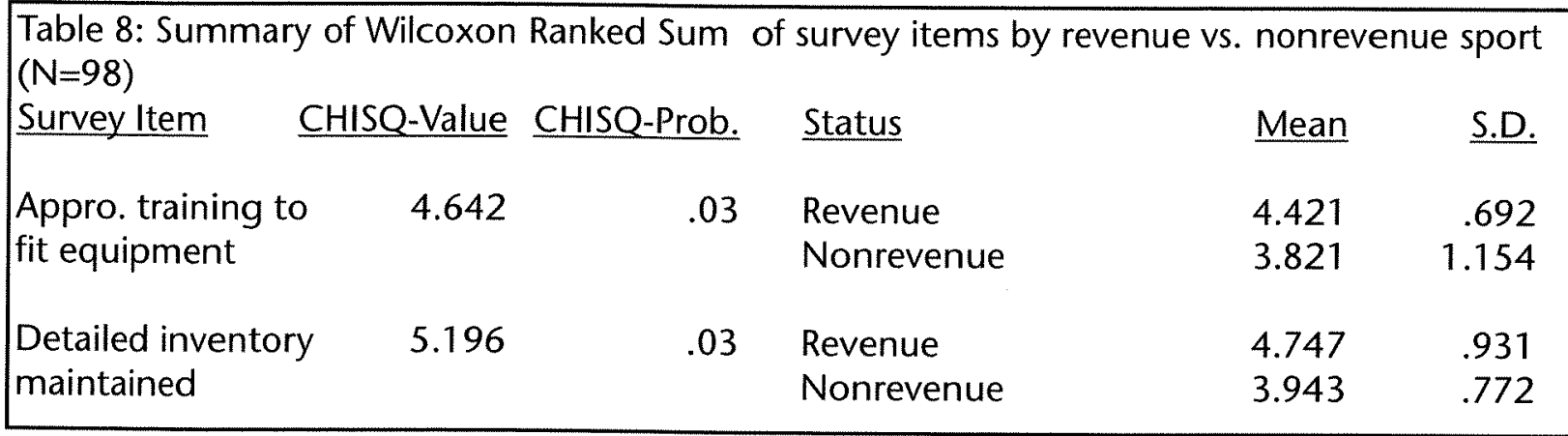

amine how the type and level of coaches degree affected the conceptual areas which revealed no significant differences. Also, there were no discernible relationships among staff size, certification, coaching experience or risk managers on staff, coach's support of regulation or various risk management practices.

The majority of coaches suggest that the university should be the authority to develop and enforce regulation of risk management behavior. This was true for every survey item. According to Gray's articles, athletic directors consistently indicate that they are effectively managing risk within their departments, and yet one sees that appropriate strategies are not in place. Apparently, self regulation by university administration is not solving the problem. Coaches suggest that regulation should not be delegated to the NCAA, the SEC, or sport specific national governing bodies; therefore, the question remains, who should be responsible? In this litigious society, the search for a remedy to sportrelated injuries is likely to continue. Coaches and administrators would do well to work as a team to develop and enforce risk management practices to reduce the potential for exposure to litigation and the resultant financial loss. Future study in this area may illuminate alternatives for athletic departments to manage risk.

\section{Implications}

This study seems to suggest that although there is interest in regulation as shown through strong feelings that risk management strategies should be regulated, the reality seems to be that coaches do not want that regulation coming from an outside source. They want regulation to be done in-house, which is typical of most professions. Perhaps, then, greater exposure by coaches and athletic directors to risk management strategies, their importance, and methods for enforcement should be provided. Help with methods and development for such things as emergency action plans may increase compliance voluntarily. This type of training seems to be of particular interest to coaches of women, revenue sports, and combined sports.

\section{References}

Baley, J.A., \& Matthews, D.L. (1984). Law and liability in athletics, physical education, and recreation. Boston, MA: Allyn and Bacon, Inc.

Dougherty, N.J., Auxter, D., Goldberger, A.S., \& Heinzmann, G.S. (1994). Sport, physical activity, and the law. Champaign, IL: Human Kinetics Publishing.

Gray, G.R. (1992). Risk management behaviors of wilderness outfitters and guides in North America. Lournal of Legal Aspects of Sport, 2(1), 101-109.

Gray, G.R. (1995). Risk management behaviors of high school principals in the supervision of their high school physical education and athletic programs. Journal of Legal Aspects of Sport, 5(1), 52-59.

Gray, G.R., \& Crowell, S.E. (1993). Risk management behaviors in NCAA Division I athletic programs. Journal of Legal Aspects of Sport, 3 (2), 71-87.

Gray, G.R., \& McKinstrey, I.P. (1994). Risk management behaviors of NCAA Division III head football coaches. Lournal of Legal Aspects of Sport, 4(2), 63-71.

Gray, G.R., \& Parks, S.R. (1991). Risk management behaviors among high school athletic directors. Lournal of Legal Aspects of Sport, 1, 57-65.

Hart, J.E., \& Ritson, R.J. (1993). Liability and safety in physical education and sport. Reston, VA: AAHPERD.

Hronek, B.R., \& Spengler, J.O. (1997). Legal liability in recreation and sports. Champaign, IL: Sagamore Publishing.

McKinnon, M.C., \& McCormick, R.A. (1992). Sports law. Detroit, MI: Lupus Publications, Ltd.

Pyles, C.D., \& Pyles, R.B. (1992). Risk management of sports facilities. Journal of Legal Aspects of Sport, 2(1), 53-64. 